\title{
Purification of Synthetic Gas from Fine Coal Waste Gasification as a Clean Fuel
}

\author{
Muhammad Faizal ${ }^{1 *}$, Muhammad Said ${ }^{1}$, Enggal Nurisman ${ }^{1}$, Nabila Aprianti ${ }^{1,2}$ \\ 1 Chemical Engineering Department, Faculty of Engineering, Universitas Sriwijaya, \\ J. Raya Palembang-Prabumulih KM 32 Indralaya, Ogan Ilir, Sumatera Selatan 30662, Indonesia \\ 2 Doctoral Program of Environmental Science, Graduate School, Universitas Sriwijaya, \\ Jl. Padang Selasa No.524, Palembang 30139, South Sumatra, Indonesia \\ * Corresponding author's e-mail: muhammadfaizal@unsri.ac.id
}

\begin{abstract}
The presence of $\mathrm{CO}_{2}$ in the syngas is attracting more attention in terms of reducing the greenhouse gas emissions in its utilisation. The aim of this study was to purify syngas from the $\mathrm{CO}_{2}$ content of fine coal gasification. Fine coal is gasified with and without absorption using $\mathrm{CaO}$, which is hydrated to $\mathrm{Ca}(\mathrm{OH})_{2}$ in the modified updraft gasifier at $450-700{ }^{\circ} \mathrm{C}$. Apart from investigating the $\mathrm{CO}_{2}$ absorption process, the gasification process also evaluates the influence of temperature in terms of its synergy with $\mathrm{Ca}(\mathrm{OH})_{2}$. The best conditions for the gasification process are achieved at $700{ }^{\circ} \mathrm{C}$. The content of $\mathrm{CO}_{2}$ was proven to be well absorbed, which is characterised by a decrease in the $\mathrm{CO}_{2}$ content and an increase in $\mathrm{H}_{2}$ in syngas. After the absorption process, the $\mathrm{H}_{2}$ content obtained increased from $42.6 \mathrm{~mole} \%$ to $48.8 \mathrm{~mole} \%$ of $\mathrm{H}_{2}$ at $700^{\circ} \mathrm{C}$. The $\mathrm{H}_{2}$ ratio also increased after absorption to 2.57 from the previous value of 2.23 . The highest absorption efficiency of $\mathrm{CO}_{2}$ by $\mathrm{Ca}(\mathrm{OH})_{2}$ occurred at $700^{\circ} \mathrm{C}$ at $50.63 \%$. With an increase in temperature in the gasification process with absorption, the $\mathrm{CO}_{2}$ content decreased dramatically from 16.9 mole $\%$ to $3.9 \%$. $\mathrm{Ca}(\mathrm{OH})_{2}$ has good absorption power at $\mathrm{CO}_{2}$ at high temperatures.
\end{abstract}

Keywords: Absorption, $\mathrm{CO}_{2}$ capture, $\mathrm{Ca}(\mathrm{OH})_{2}$, fine coal, hydration

\section{INTRODUCTION}

The use of carbon resources to produce clean fuel is desired to overcome fossil fuel depletion and the resulting environmental problems. In the process of converting a carbon material into energy, minimization of the $\mathrm{CO}_{2}$ emissions must be considered properly. According to the Ministry of Energy and Mineral Resources of Republic Indonesia (2018), the total amount of coal resources in Indonesia is estimated to reach 105 billion tons, about 21 billion tons of which is reserve; $60 \%$ of the reserve coal in Indonesia consists of low rank coal sub-bituminous with the calories content less than $6100 \mathrm{cal} / \mathrm{gram}$. Coal mining in Indonesia, which adopts an open pit mining system, cannot prevent fine coal waste from the production unit and is exposed to the air, watershed and land (Adiansyah et al., 2017; Zhang et al., 2018). This fine material from low-rank coal is very promising for use in the production of environmentally friendly synthetic gases. The synthetic gas from gasification is a mixture of $\mathrm{CO}, \mathrm{H}_{2}, \mathrm{CH}_{4}, \mathrm{CO}_{2}$, and other gases. Syngas can be converted easily into environmentally friendly fuel and used as raw material to produce other useful chemical products.

$\mathrm{CO}_{2}$ is a by-product of the gasification process, which can contribute to the emissions to the atmosphere. The reduced $\mathrm{CO}_{2}$ continuously encourages carbon gasification and methane reform and shifts the water gas reaction to the product side so that the syngas is rich in hydrogen (Chen et al., 2020; Chen and Chen, 2020). The heat released from the carbonation process makes up most of the heat supply for the gasification process. The gasification process, producing syngas with low $\mathrm{CO}_{2}$ emission involves absorbing or capturing 
$\mathrm{CO}_{2}$ in the syngas. Carbon capture and storage are economical and efficient strategies for reducing $\mathrm{CO}_{2}$ (Ghaemi and Behroozi, 2020; Wu et al., 2020). The Ca-based sorbent is very attractive for use as a $\mathrm{CO}_{2}$ absorber at high temperatures, apart from being abundant, environmentally friendly, and inexpensive. It is also because of its appropriate kinetics and $\mathrm{CO}_{2}$ absorption capacity (Soleimanisalim et al., 2016). Calcium oxide plays an essential role in removing $\mathrm{CO}_{2}$ in syngas through the absorption process in the gasification process. The water-gas shift reaction takes place more dominantly after $\mathrm{CO}_{2}$ is absorbed so that the purity of syngas, especially $\mathrm{H}_{2}$, increases (Dou et al., 2016). However, inorganic or dissolved organic calcium compounds derived from limestone are preferred to manufacture synthetic Ca-based absorbers (Soleimanisalim et al., 2017).

The fixation of $\mathrm{CO}_{2}$ through the production of insoluble carbonate salts, such as through the carbonation of an acidic solution that absorbs $\mathrm{CO}_{2}$, is another option for capturing $\mathrm{CO}_{2}$. The aqueous solution of $\mathrm{Ca}(\mathrm{OH})_{2}$ is used as an effective solvent to absorb $\mathrm{CO}_{2}$ because of its various beneficial features. $\mathrm{CaCO}_{3}$ is formed after $\mathrm{CO}_{2}$ has been successfully absorbed in the gasifier and can be regenerated (Hafner, Schmid, and Scheffknecht, 2021). Precipitation of $\mathrm{CaCO}_{3}$ from the carbonation of a $\mathrm{Ca}(\mathrm{OH})_{2}$, solution is a widespread reaction, commonly observed in nature. Considering that the cost and stock of the $\mathrm{CaO}$ sources in Indonesia are abundant and promising, so the absorption of $\mathrm{CO}_{2}$ in the gasification process is very relevant for studying. $\mathrm{CaO}$-enhanced gasification is a promising technology for the production of hydrogen-rich synthetic gas (Mostafavi et al., 2016; Sun and $\mathrm{Wu}, 2019$ ).

The studies on absorption using $\mathrm{Ca}(\mathrm{OH})_{2}$ both as an absorbent and as a catalyst have been carried out by Soomro et al. (2018); Kumar et al. (2019); Kim, Jo, and Kim (2020). The research by $\mathrm{Li}$ et al. (2017) found that calcined $\mathrm{CaO}$ acts as an absorbent and a catalyst in the water-gas shift reaction in corn stalk gasification. Furthermore, in coal gasification, $\mathrm{Ca}(\mathrm{OH})_{2}$ acts as an active catalyst that decomposes tar to increase the gas yield and hydrogen concentration, which correlates with $\mathrm{CO}_{2}$ absorption (Shuai et al., 2015; Jiang et al., 2018). Although several studies have been submitted regarding the absorption of $\mathrm{CO}_{2}$ using $\mathrm{CaO}$ or $\mathrm{Ca}(\mathrm{OH})_{2}$ in the gasification process, the research on $\mathrm{CO}_{2}$ absorption in syngas from the fine coal gasification process using $\mathrm{Ca}(\mathrm{OH})_{2}$ has not been intensively studied by researchers. Therefore, this study aimed to produce syngas with minimal $\mathrm{CO}_{2}$ in a specific temperature range using hydrated $\mathrm{CaO}$. The gas composition was evaluated to determine the role and synergy between the gasification temperature and the absorbent. The following reactions (R1-4) are occurring within the gasifier in the gasification and purification process:

$$
\mathrm{C}_{(s)}+\mathrm{CO}_{2(g)} \leftrightarrow 2 \mathrm{CO}_{(s)}
$$

(Boudouard reaction)

$$
\begin{aligned}
& \mathrm{C}_{(\mathrm{s})}+\mathrm{H}_{2} \mathrm{O}_{(\mathrm{g})} \leftrightarrow \mathrm{CO}_{(\mathrm{g})}+\mathrm{H}_{2}(\mathrm{~g}) \\
& \quad \text { (Reforming char reaction) }
\end{aligned}
$$

$$
\mathrm{CO}_{(\mathrm{g})}+\mathrm{H}_{2} \mathrm{O}_{(\mathrm{g})} \rightarrow \mathrm{CO}_{2(\mathrm{~g})}+\mathrm{H}_{2(\mathrm{~g})}
$$

(Water-gas shift reaction)

$$
\begin{gathered}
\mathrm{CaO}_{(\mathrm{s})}+\mathrm{H}_{2} \mathrm{O}_{(\mathrm{g})} \rightarrow \mathrm{Ca}(\mathrm{OH})_{2(s)} \\
\text { (CaO hydration) }
\end{gathered}
$$

$$
\begin{gathered}
\mathrm{Ca}(\mathrm{OH})_{2(\mathrm{~s})}+\mathrm{CO}_{2(\mathrm{~g})} \rightarrow \mathrm{CaCO}_{3(\mathrm{~s})}+\mathrm{H}_{2} \mathrm{O}_{(\mathrm{g})} \\
\left(\mathrm{Ca}(\mathrm{OH})_{2} \text { carbonation }\right)
\end{gathered}
$$

\section{MATERIALS AND METHODS}

\section{Raw materials}

The fine coal used in this research having the size below $3 \mathrm{~mm}$, was supplied by a coal mining at Sumatera Selatan. The proximate and ultimate analyses of the fine coal are shown in Table 1 in order to investigate the characteristics of fine coal. The gasifier used was a fixed bed type made of stainless steel. Air was used as the gasification agent in this process. The condition inside gasifier was temperature $450^{\circ} \mathrm{C}, 550^{\circ} \mathrm{C}, 650^{\circ} \mathrm{C}$ and $700^{\circ} \mathrm{C}$. The gasifier was isolated to prevent heat release and gas leakage, as well as the two pipes of input stream for gasification agent and output stream for gas product. A flowmeter was installed to measure the flowrate of gasification agent needed. The flow diagram of the gasification process refers to the previous work (Aprianti et al., 2020). $\mathrm{CaO}$ was used in the form hydrated by $\mathrm{H}_{2} \mathrm{O}$ becoming calcium hydroxide $\left(\mathrm{Ca}(\mathrm{OH})_{2}\right)(\mathrm{R} 4)^{2}$. 


\section{Gasification procedure}

The samples were placed into the gasifier and the coal was ignited to $450-700^{\circ} \mathrm{C}$, then the mixture of oxygen and air was supplied continuously as the agents of gasification to sustain the gasification process. In this research, the fine coal gasification was carried out under different temperature. The syngas produced then accumulated into gas samplers to be analysed by gas chromatography.

\section{Gas analysis}

The syngas produced accumulated into gas sampler bag to analyse by Perkin Elmer Clarus 680 Gas Chromatography equipped flame ionization detector (FID). The success of the gasification process and the quality of syngas are evaluated through the gas ratio and heating value of syngas (Eq. 1-2).

$$
\begin{gathered}
\mathrm{HHV}_{\text {gas }}= \\
=\left((30.18 \times \mathrm{CO})+\left(30.52 \times \mathrm{H}_{2}\right)+\left(95 \times \mathrm{CH}_{4}\right)\right) \times \\
\times 4.1868\left(\mathrm{MJ} / \mathrm{NM}^{3}\right) \\
=\left((30 \times \mathrm{CO})+\left(25.7 \times \mathrm{H}_{2}\right)+\left(85.4 \times \mathrm{CH}_{4}\right)\right) \times \\
\times 4.2\left({\left.\mathrm{MJ} / \mathrm{NM}^{3}\right)}=\right.
\end{gathered}
$$

\section{RESULTS AND DISCUSSION}

\section{Fine coal characteristics by proximate and ultimate analysis}

The proximate, ultimate, and calorific analyses in Table 1 provide important insights regarding the chemical properties of fine coal materials. Proximate analysis of fine coal was carried out to identify its composition in moisture, which was later found to be $16.77 \%$. The volatile material of fine coal burning into gas in the nitrogen atmosphere was $40.74 \%$, while the inorganic material in fine coal (ash) was $4.13 \%$. Fine coal is expected to have high gasification efficiency with risks such as clogging, slag, and minor dirt due to low ash. Fine coal contains $38.37 \%$ fixed carbon. This result is relatively low compared to raw coal in similar studies (Yan et al., 2021; Vega, Díaz-Faes, and Barriocanal, 2021). The moisture content in fine coal will affect the gasification process. When the water content is high, some of the heat energy will be used to evaporate water in the drying zone. Increasing the volatile matter can result in greater gas conversion yields (Aprianti et al., 2021). Fine coal is mostly composed of minerals. The calorific value of fine coal is relatively high because classified as a sub-bituminous coal type. The high calorific value expected to make the syngas produced also has a high calorific value.

The ultimate fine coal analysis consists of carbon, hydrogen, oxygen, nitrogen and sulphur. The carbon composition in fine coal was $69.04 \%$, which contributes to the $\mathrm{CO}$ formation in syngas and a high calorific value. Meanwhile, the $\mathrm{H}_{2}$ and $\mathrm{O}_{2}$ content in the material causes a decrease in the calorific value. In fine coal, $\mathrm{H}_{2}$ was found only $4.78 \% . \mathrm{N}_{2}$ was around $0.97 \%$, because it is an inert gas and is not flammable. The portion of sulphur in this coal type was $0.45 \%$. Oxidized sulphur can later cause air pollution and contribute to the formation of detrimental acid rain. The low nitrogen and sulphur content in fine coal minimise the possibility of $\mathrm{NO}_{\mathrm{x}}$ and $\mathrm{SO}_{\mathrm{x}}$ formation along the updraft gasification process. Thus, it can be predicted that the resulting syngas is highly desirable for fuel, chemical synthesis and methanol (Mansur et al., 2020).

\section{Effect of reaction temperature on syngas production}

Figure 1 shows the synthetic gas after the absorption process at different temperatures. The $\mathrm{CO}_{2}$ concentration has decreased with increasing gasification temperature from $450^{\circ} \mathrm{C}$ to $700^{\circ} \mathrm{C}$. This situation is due to the fact that the $\mathrm{CO}_{2}$

Table 1. Proximate and ultimate analyses of subbituminous fine coal

\begin{tabular}{|l|c|c|}
\hline \multicolumn{1}{|c|}{ Parameter } & Unit & Air dry basis \\
\hline Total moisture & $\%$ & 16.77 \\
\hline Ash content & $\%$ & 4.13 \\
\hline Volatile matter & $\%$ & 40.74 \\
\hline Fixed carbon & $\%$ & 38.37 \\
\hline Total sulphur & $\%$ & 0.21 \\
\hline Gross Calorific Value & $\mathrm{MJ} / \mathrm{kg}$ & 21.54 \\
\hline Carbon & $\%$ & 69.04 \\
\hline Hydrogen & $\%$ & 4.78 \\
\hline Oxygen & $\%$ & 13.62 \\
\hline Nitrogen & $\%$ & 0.97 \\
\hline Sulphur & $\%$ & 0.45 \\
\hline
\end{tabular}


content in the synthetic gas exiting the gasifier before purification shows an identical trend, where the $\mathrm{CO}_{2}$ content decreases if the gasification temperature is increased. This can be possible when the $\mathrm{CO}_{2}$ content in synthetic gas decreases, then the opportunity for the absorption process will easily occur. Hydrogen has increased significantly after the gasification temperature was raised, while methane in syngas tends to decrease. The $\mathrm{CO}$ content increases slowly with a range of $20-30 \mathrm{~mole} \%$ at $450-650^{\circ} \mathrm{C}$. When the gasification temperature reaches $700^{\circ} \mathrm{C}$, the $\mathrm{CO}$ concentration is reduced by $6.5 \mathrm{~mole} \%$ to $19 \mathrm{~mole} \%$ at the end of the process. The reaction temperature is an important parameter in the gasification process which significantly affects the equilibrium of the reaction and the resulting syngas (Aprianti et al., 2020).

\section{The effect of $\mathrm{CO}_{2}$ absorption by $\mathrm{Ca}(\mathrm{OH})_{2}$ on gas composition}

The syngas production rate for fine coal gasification with and without absorption is a maximum at a reaction temperature of $700^{\circ} \mathrm{C}$. The percentages of $\mathrm{H}_{2}$ without and with absorption were 42.6 and $48.8 \mathrm{~mole} \%$, respectively. This result shows that the $\mathrm{CO}_{2}$ produced without the absorption process inhibits the chemical reactions shown by R1 and R2, while the absorption of $\mathrm{CO}_{2}$ using $\mathrm{Ca}(\mathrm{OH})_{2}$ encourages the reaction. $\mathrm{Ca}(\mathrm{OH})_{2}$ has increased the $\mathrm{H}_{2}$ concentration effectively and decreased the gasification equilibrium temperature (Xiong et al., 2020). The $\mathrm{H}_{2}$ concentration can be improved with the addition of $\mathrm{Ca}(\mathrm{OH})_{2}$, and the $\mathrm{H}_{2}$ concentration is more sensitive to temperature by the incorporation of $\mathrm{Ca}(\mathrm{OH})_{2}$.

The carbon monoxide content was observed to increase at $450-550^{\circ} \mathrm{C}$, but after passing through this phase, $\mathrm{CO}$ decreased when the temperature is increased to $700^{\circ} \mathrm{C}$ with a final yield of $19 \mathrm{~mole} \%$. This is possible because the watergas shift reaction also increases hydrogen (R3). During the gasification process, methane is consumed through the methane dry reforming reaction. The two reactions are associated with each other and occur in the reduction zone (Kumari and Vairakannu, 2018). Regardless of whether absorption using $\mathrm{Ca}(\mathrm{OH})_{2}$ was applied or not, the amount of methane that fell was not much different (19.5 mole $\%$ and 18 mole $\%)$ at maximum temperature.
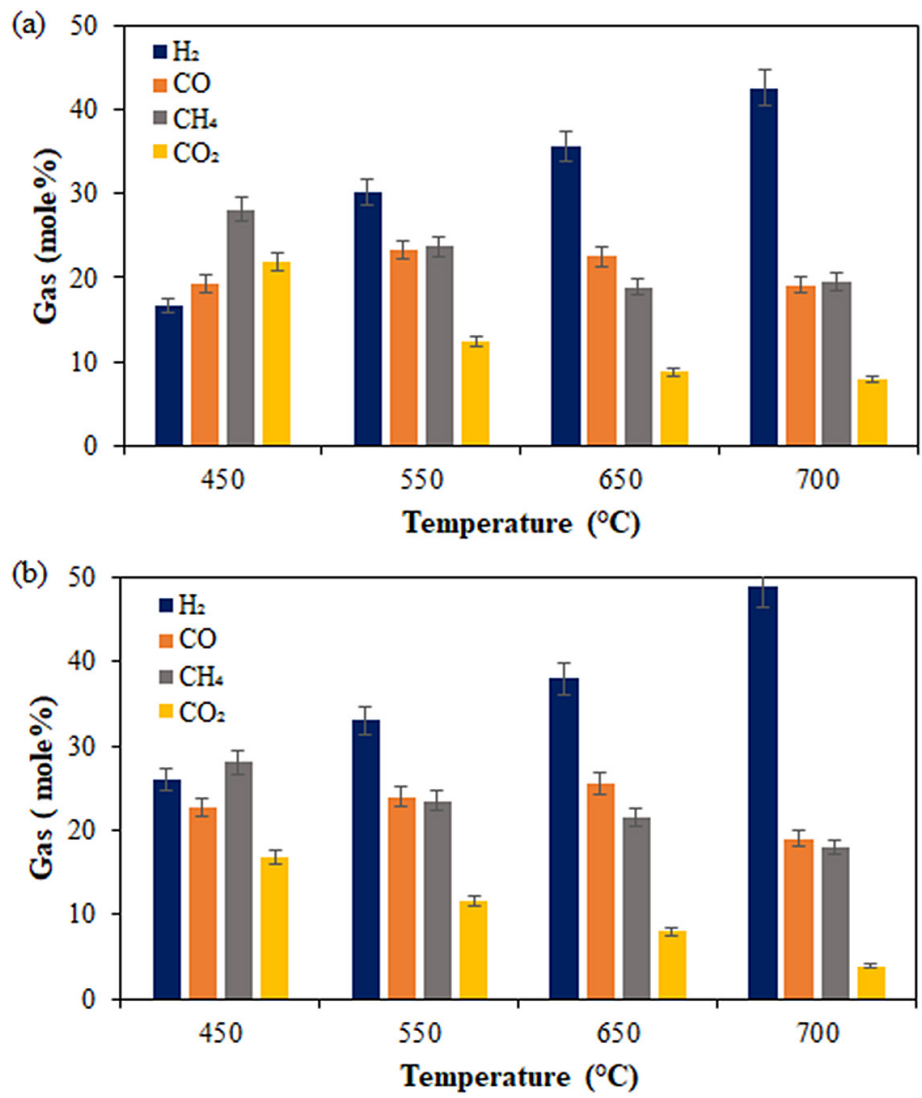

Figure 1. Composition of gas from gasification (a) before and (b) after purification 
By adding $\mathrm{Ca}(\mathrm{OH})_{2}$, the higher hydrogen concentration will be obtained under sufficient reaction conditions. In addition, the percentage of gas volume is found to be lower when the gasification process is carried out without the addition of $\mathrm{Ca}(\mathrm{OH})_{2}$. Calcium hydroxide, together with the availability of steam, actively absorbed carbon dioxide. Furthermore, the volume of $\mathrm{CO}_{2}$ and $\mathrm{CO}$ is decreased whilst $\mathrm{H}_{2}$ is more dominant in syngas by $\mathrm{Ca}(\mathrm{OH})_{2}$. Syngas purification is more likely to occur in gasification after $\mathrm{CO}_{2}$ has been removed. At the stage between $550-650^{\circ} \mathrm{C}$, the addition of $\mathrm{Ca}(\mathrm{OH})_{2}$ only contributes slightly to the decrease in $\mathrm{CO}_{2}$, but then the performance increases again at $700^{\circ} \mathrm{C}$. This is possible because $\mathrm{Ca}(\mathrm{OH})_{2}$ has decreased its ability to absorb $\mathrm{CO}_{2}$ under these conditions.

$\mathrm{CO}_{2}$ reduced by $\mathrm{Ca}(\mathrm{OH})_{2}$ is shown in Figure 2. The highest reduction in $\mathrm{CO}_{2}$ occurs at the initial gasification temperature $\left(450^{\circ} \mathrm{C}\right)$. The highest $\mathrm{CO}_{2}$ content $(21.8$ mole $\%$ ) was successfully reduced by $4.9 \mathrm{~mole} \%$ in this initial state. $\mathrm{Ca}(\mathrm{OH})_{2}$ reduced $22.48 \%$ of the total $\mathrm{CO}_{2}$ in syngas at $450^{\circ} \mathrm{C} . \mathrm{CO}_{2}$ remained at the end of the gasification process in a small volume of $3.9 \mathrm{~mole} \%$. The absorption of $\mathrm{CO}_{2}$ in syngas referred to as the carbonation reaction of $\mathrm{Ca}(\mathrm{OH})_{2}$ in gasification. At higher temperatures, the calcination reaction is preferred in the absorption of $\mathrm{CO}_{2}$. At high temperatures, the $\mathrm{Ca}(\mathrm{OH})_{2}$ particles decompose to become $\mathrm{CaO}$ just before $\mathrm{CO}_{2}$ is absorbed (Li et al., 2015; Yanase, Sasaki, and Kobayashi, 2017). The absorption of $\mathrm{CO}_{2}$ reduces its percentage volume in the syngas, leading to the formation of $\mathrm{H}_{2}$, preferably in this state according to the water-gas shift reaction. Hydrogen increases along with temperature and $\mathrm{Ca}(\mathrm{OH})_{2}$ addition. Hydrogen increased by 6.2 mole $\%$ while $\mathrm{CH}_{4}$ slightly decreased after the

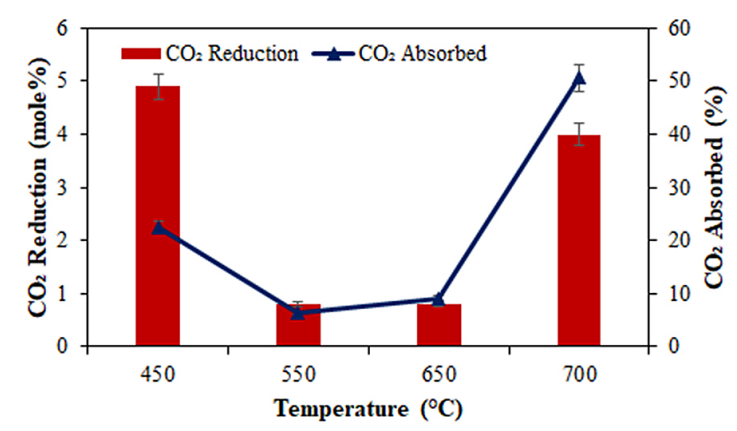

Figure 2. Absorbed $\mathrm{CO}_{2}$ in syngas by $\mathrm{Ca}(\mathrm{OH})_{2}$ solution absorbent application. These results indicate that the absorption of $\mathrm{CO}_{2}$ by $\mathrm{Ca}(\mathrm{OH})_{2}$ affects the rate of $\mathrm{H}_{2}$ production. This situation has been reported in several previous studies (Hwang, Kobayashi, and Kawamoto, 2014; Chen et al., 2017; Lazzarotto et al., 2020). The reaction between $\mathrm{Ca}(\mathrm{OH})_{2}$ and $\mathrm{CO}_{2}$ formed $\mathrm{CaCO}_{3}$ according to the $\mathrm{Ca}(\mathrm{OH})_{2}$ carbonation reaction (R5).

\section{Gas ratio and heating value of syngas from fine coal}

The gas ratio from fine coal gasification is evaluated by the $\mathrm{H}_{2} / \mathrm{CO}$ and CG/NCG ratio. The $\mathrm{H}_{2} / \mathrm{CO}$ ratio determines the usefulness of the syngas produced (Figure 3). The highest $\mathrm{H}_{2} / \mathrm{CO}$ ratio was achieved at $700^{\circ} \mathrm{C}$ at 2.23 . The $\mathrm{H}_{2} / \mathrm{CO}$ ratio increases along with temperature. The high $\mathrm{H}_{2} /$ $\mathrm{CO}$ ratio is in line with the facts in the previous section that there has been an increase in $\mathrm{H}_{2}$. As well as the CG/NCG ratio, the $\mathrm{CO}_{2}$ content that continues to decline coupled with the increase in other combustible gases causes the $\mathrm{CG} / \mathrm{NCG}$ ratio to continue to increase. In order to see the role of $\mathrm{Ca}(\mathrm{OH})_{2}$ as an absorber, gasification has been carried out at the same temperature range. The results show that $\mathrm{Ca}(\mathrm{OH})_{2}$ has increased the $\mathrm{H}_{2} / \mathrm{CO}$ ratio for almost all temperatures except at $650^{\circ} \mathrm{C}$. The highest $\mathrm{H}_{2} / \mathrm{CO}$ ratio occurred for the gasification process with the absorption of 2.57. The CG/NCG ratio after application of $\mathrm{Ca}(\mathrm{OH})_{2}$ shows a positive effect at each reaction temperature. The CG/NCG ratio before using the absorbent reached 4.83 , whereas after using the absorbent it increased to 7.40 at $700^{\circ} \mathrm{C}$.

The heating value represents the chemical energy contained in syngas. Humidity affects the heating value of syngas. The pattern of HHV and LHV results obtained between absorption with

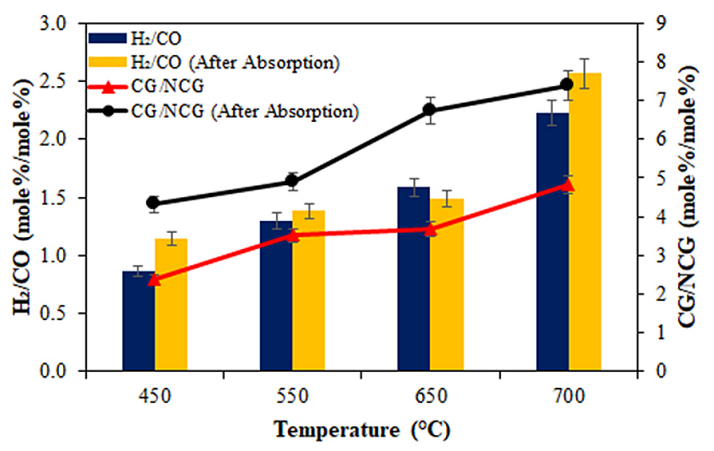

Figure 3. Gas ratio of syngas 


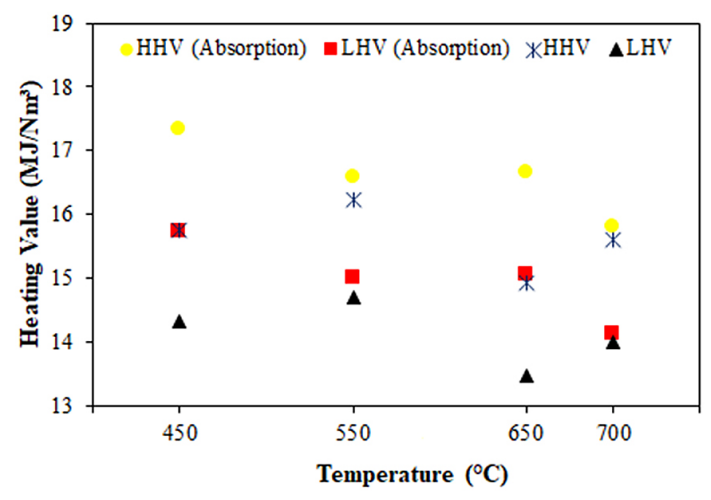

Figure 4. HHV and LHV syngas

and without absorption has a way similar to temperature changes, as illustrated by Figure 4 . The highest $\mathrm{HHV}$ and LHV were achieved at $450^{\circ} \mathrm{C}$ with the $\mathrm{Ca}(\mathrm{OH})_{2}$ absorbent of $17.34 \mathrm{MJ} / \mathrm{Nm}^{3}$ and $15.72 \mathrm{MJ} / \mathrm{Nm}^{3} . \mathrm{CH}_{4}$ decreases rapidly when the temperature is increased from $450^{\circ} \mathrm{C}$ to $700^{\circ} \mathrm{C}$, which also has a large effect on the concentration of HHV and LHV syngas. The results show that there has been a significant decrease in HHV from 17.34 to $15.8 \mathrm{MJ} / \mathrm{Nm}^{3}$. Although the $\mathrm{H}_{2}$ concentration appears to increase over $450-700^{\circ} \mathrm{C}$, its heating value is much lower than that of $\mathrm{CH}_{4}$ so that the HHV and LHV syngas gradually decrease.

\section{CONCLUSIONS}

The experimental results demonstrate that the gasification of fine coal with $\mathrm{Ca}(\mathrm{OH})_{2}$ sorbent have a significant impact on syngas producing at the temperature range of $450-700^{\circ} \mathrm{C}$. The gas analysis reveal that $\mathrm{Ca}(\mathrm{OH})_{2}$ absorbs the $\mathrm{CO}_{2}$ content throughout the temperature rise. Additionally, $\mathrm{H}_{2}$ increased significantly at $700^{\circ} \mathrm{C}$ from $42.6 \mathrm{~mole} \%$ to $48.8 \mathrm{~mole} \%$. This trend also applies to the $\mathrm{H}_{2} / \mathrm{CO}$ ratio, which consistently rises to reach a ratio of 2.57 .

\section{Acknowledgements}

The authors express their gratitude to Universitas Sriwijaya for research financial support through Competitive Research Scheme (Riset Unggulan Kompetitif dana PNBP Universitas Sriwijaya tahun 2020) and Chemical Engineering Department of Universitas Sriwijaya. The authors thank PT. Pertamina RU III Plaju for gas analysis.

\section{REFERENCES}

1. Adiansyah J.S., Haque N., Rosano M., and Biswas W. 2017. Application of a life cycle assessment to compare environmental performance in coal mine tailings management. Journal of Environmental Management, 199, 181-91. https://doi. org/10.1016/j.jenvman.2017.05.050.

2. Aprianti N., Faizal M., Said M., and Nasir S. 2020. Valorization of Palm Empty Fruit Bunch Waste for Syngas Production through Gasification. Journal of Ecological Engineering, 21(7), 17-26. https://doi. org/10.12911/22998993/125461.

3. Aprianti N., Faizal M., Said M., and Nasir S. 2021. Catalytic gasification of oil palm empty fruit bunch by using Indonesian bentonite as the catalyst. Journal of Applied Engineering Science, 1-10. https:// doi.org/10.5937/jaes0-28781.

4. Chen S., Zhao Z., Soomro A., Ma S., Wu M., Sun Z, and Xiang W. 2020. Hydrogen-rich syngas production via sorption-enhanced steam gasification of sewage sludge. Biomass and Bioenergy, 138, 105607. https://doi.org/10.1016/j.biombioe.2020.105607.

5. Chen W.H., and Chen C.Y. 2020. Water gas shift reaction for hydrogen production and carbon dioxide capture: A review. Applied Energy, 258, 114078. https://doi.org/10.1016/j.apenergy.2019.114078.

6. Chen Z, Dun Q., Shi Y., Lai D., Zhou Y., Gao S., and $\mathrm{Xu}$ G. 2017. High quality syngas production from catalytic coal gasification using disposable $\mathrm{Ca}(\mathrm{OH}) 2$ catalyst. Chemical Engineering Journal, 316, 842849. https://doi.org/10.1016/j.cej.2017.02.025.

7. Dou B., Wang K., Jiang B., Song Y., Zhang C., Chen H., and Xu Y. 2016. Fluidized-bed gasification combined continuous sorption-enhanced steam reforming system to continuous hydrogen production from waste plastic. International Journal of Hydrogen Energy, 41(6), 3803-3810. https://doi.org/10.1016/j. ijhydene.2015.12.197.

8. Ghaemi A., and Behroozi A.H. 2020. Comparison of hydroxide-based adsorbents of $\mathrm{Mg}(\mathrm{OH}) 2$ and $\mathrm{Ca}(\mathrm{OH}) 2$ for $\mathrm{CO} 2$ capture- Utilization of response surface methodology, kinetic, and isotherm modeling. Greenhouse Gases Science and Technology, 10(5), 948-964. https://doi.org/10.1002/ghg.2015.

9. Hafner S., Schmid M., and Scheffknecht G. 2021. Parametric study on the adjustability of the syngas composition by sorption-enhanced gasification in a dual-fluidized bed pilot plant. Energies, 14(2), 399. https://doi.org/10.3390/en14020399.

10. Hwang I.H., Kobayashi J., and Kawamoto K. 2014. Characterization of products obtained from pyrolysis and steam gasification of wood waste, RDF, and RPF. Waste Management, 34(2), 402-410. https:// doi.org/10.1016/j.wasman.2013.10.009.

11. Jiang L., Hu S., Syed-Hassan S.S.A., Xu K., Shuai C., Wang Y., Su S., and Xiang J. 2018. Hydrogen-rich 
gas production from steam gasification of lignite integrated with $\mathrm{CO}_{2}$ capture using dual calciumbased catalysts: An experimental and catalytic kinetic study. Energy and Fuels, 32(2), 1265-1275. https://doi.org/10.1021/acs.energyfuels.7b03213.

12. Kim, J.Y., Jo Y.M., and Kim S.B. 2020. De-dusting in biomass gasification process using a coated bag filter. Biomass Conversion and Biorefinery. https:// doi.org/10.1007/s13399-020-00990-w.

13. Kumar S., Wang Z., Kang Z., Xia J., Whiddon R., He Y., Gul-e-Rana J., Bairq Z.A.S., and Cen K. 2019. Influence of temperature and $\mathrm{Ca}(\mathrm{OH}) 2$ on releasing tar and coal gas during lignite coal pyrolysis and char gasification. Chinese Journal of Chemical Engineering, 27(11), 2788-2798. https:// doi.org/10.1016/j.cjche.2019.05.013.

14. Kumari G, and Vairakannu P. 2018. $\mathrm{CO}_{2}-\mathrm{O}_{2}$ dry reforming based underground coal gasification using low and high ash Indian coals. Fuel, 216, 301-312. https://doi.org/10.1016/j.fuel.2017.11.117.

15. Lazzarotto, I.P., Ferreira S.D., Junges J., Bassanesi G.R., Manera C., Perondi D., and Godinho M. 2020. The role of $\mathrm{CaO}$ in the steam gasification of plastic wastes recovered from the municipal solid waste in a fluidized bed reactor. Process Safety and Environmental Protection, 140, 60-67. https://doi. org/10.1016/j.psep.2020.04.009.

16. Li B., Yang H., Wei L., Shao J., Wang X., and Chen H. 2017. Absorption-enhanced steam gasification of biomass for hydrogen production: Effects of Calcium-based absorbents and $\mathrm{NiO}$-based catalysts on corn stalk pyrolysis-gasification. International Journal of Hydrogen Energy, 42(9), 5840-5848. https:// doi.org/10.1016/j.ijhydene.2016.12.031.

17. Li Z., Wang Y., Yao H., and Lin S. 2015. Novel $\mathrm{CO}_{2}$ sorbent: $\mathrm{Ca}(\mathrm{OH})_{2}$ with high strength. Fuel Processing Technology, 131, 437-442. https://doi. org/10.1016/j.fuproc.2014.12.023.

18. Mansur F.Z., Faizal C.K.M., Monir M.U., Samad N.A.F.A., Atnaw S.M., and Sulaiman S.A. 2020. Co-gasification between coal/sawdust and coal/ wood pellet: A parametric study using response surface methodology. International Journal of Hydrogen Energy, 45(32), 15963-15976. https://doi. org/10.1016/j.ijhydene.2020.04.029.

19. Mostafavi E., Mahinpey N., Rahman M., Sedghkerdar M.H., and Gupta R. 2016. High-purity hydrogen production from ash-free coal by catalytic steam gasification integrated with dry-sorption $\mathrm{CO}_{2}$ capture. Fuel, 178, 272-282. https://doi.org/10.1016/j. fuel.2016.03.026.

20. Shuai C., Hu S., He L., Xiang J., Su S., Sun L., Jiang L., Wang Y., Chen Q., Liu C., Chi H. 2015. Performance of $\mathrm{CaO}$ for phenol steam reforming and water-gas shift reaction impacted by carbonation process. International Journal of Hydrogen Energy, 40(39), 13314-13322. https://doi.org/10.1016/j. ijhydene.2015.07.167.

21. Soleimanisalim A.H., Sedghkerdar M.H., Karami D., and Mahinpey N. 2017. Effects of second metal oxides on zirconia-stabilized Ca-based sorbent for sorption/catalyst integrated gasification. Journal of Environmental Chemical Engineering, 5(1), 12811288. https://doi.org/10.1016/j.jece.2017.01.047.

22. Soleimanisalim A.H., Sedghkerdar M.H., Karami D., and Mahinpey N. 2016. The effects of refractory zirconium-based ceramic dopants on the stability performance of synthetic Ca-based sorbents prepared by co-precipitation method in cyclic $\mathrm{CO} 2$ capture operations. Journal of Natural Gas Science and Engineering, 36, 1056-1061. https://doi. org/10.1016/j.jngse.2016.09.010.

23. Soomro A., Chen S., Ma S., Xu C., Sun Z., and Xiang W. 2018. Elucidation of syngas composition from catalytic steam gasification of lignin, cellulose, actual and simulated biomasses. Biomass and Bioenergy, 115, 210-222. https://doi.org/10.1016/j. biombioe.2018.05.002.

24. Sun H., and Wu C. 2019. Autothermal CaO looping biomass gasification for renewable syngas production. Environmental Science and Technology, 53(15), 9298-9305. https://doi.org/10.1021/acs. est.9b01527.

25. Vega M.F., Díaz-Faes E., and Barriocanal C. 2021. Influence of feedwater $\mathrm{PH}$ on the $\mathrm{CO} 2$ reactivity of hydrochars. Co-carbonisation with a bituminous coal. Renewable Energy, 170, 824-831. https://doi. org/10.1016/j.renene.2021.01.100.

26. Wu H., Xu M., Li Y., Wu J., Shen J., and Liao H. 2020. Experimental research on the process of compression and purification of $\mathrm{CO} 2$ in oxy-fuel combustion. Applied Energy, 259, 114123. https://doi. org/10.1016/j.apenergy.2019.114123.

27. Xiong S., He J., Yang Z., Guo M., Yan Y., and Ran J. 2020. Thermodynamic analysis of $\mathrm{CaO}$ enhanced steam gasification process of food waste with high moisture and low moisture. Energy, 194, 116831. https://doi.org/10.1016/j.energy.2019.116831.

28. Yan Y., Qi Y., Marshall M., Jackson W.R., Stanger A., Tran Q. A., Stanger R., and Chaffee A.L. 2021. Characterisation of coal density fractions separated from Victorian brown coal by reflux classification. Fuel, 292, 120385. https://doi.org/10.1016/j. fuel.2021.120385.

29. Yanase I., Sasaki T., and Kobayashi H. 2017. Effect of orientation of $\mathrm{CaO}$ plate-like particle on $\mathrm{CO}_{2}$ adsorption property. Powder Technology, 315, 15-21. https://doi.org/10.1016/j.powtec.2017.02.059.

30. Zhang H., Nie W., Liu Y., Wang H., Jin H., and Bao Q. 2018. Synthesis and performance measurement of environment-friendly solidified dust suppressant for open pit coalmine. Journal of Applied Polymer Science, 135(29), 46505. https://doi.org/10.1002/ app. 46505 . 